Christina Bezari. 2018. "Representations of the fin-de-siècle literary salon in the chronicles of Matilde Serao". Forum Italicum, ISSN: 0014-5858, No1, Vol. 52, pp.35-48. ${ }^{1}$

\begin{abstract}
:
This article looks into the representations of the Italian literary salon in the print press during the 1880's. Special attention is given to Matilde Serao's mediation in the private as well as in the public sphere and to her double role as salon chronicler and salon attendee. Her views with regard to the artistic and political landscape of fin-de-siècle Italy are examined through a series of chronicles on Pasquale Mancini, Baroness Magliani, Francesco De Renzis, and the salon of the literary magazine Capitan Fracassa. The representations of these salons in the fortnightly periodical Cronaca Bizantina (Rome, 1881-1886) as well as in the daily newspaper Corriere di Roma (1883-1886) offered a new reading experience to a wide audience and encouraged the creation of an imagined community of salon attendees. Salon participation is studied through the prism of the periodical press, which interpreted salon life as a meaningful collective experience and a decisive factor in the formation of culture. Serao's chronicle is also viewed as an instrument of social critique, which raised questions on the rapid expansion of mass media, the growing demand for human progress, the withering away of politics, and the growing importance of art as a means of personal expression.
\end{abstract}

Keywords: salon, print press, chronicle, Matilde Serao, fin-de-siècle.

${ }^{1}$ This work was supported by the H2020 European Research Council under the ERC Starting Grant agreement no. 639668. 


\section{Representations of the fin-de-siècle literary salon in the chronicles of Matilde Serao}

Within the relatively narrow panorama of Italian female journalists of the late nineteenth century, Matilde Serao has quite rightly been described as the most controversial. Her position as a supporter of the Italian monarchy, and more intriguingly, her opposition to the ideological and political premises of the nascent feminist movement have long been strong points of contention among scholars. Recent studies have posited that despite Serao's seemingly conservative attitude toward women's rights, she expressed her solidarity to their cause through her numerous periodical publications, where she sympathized with the hardships of middleclass female workers (Mitchell, 2008). In addition, Serao's domestic realist fiction has been discussed by scholars who underscore that the female characters of her novels are not altogether conventional since they often pose a challenge to the institution of marriage (Salsini, 1999: 100). Nevertheless, a less debated aspect of Serao's work is her double role as salon chronicler and salon participant. A comparative study of these two roles can provide a lens through which to examine her views with regard to the artistic and political landscape of fin-de-siècle Italy. It can also offer an insight into the impact of female journalists on private conversations and public debates.

Since the 1870 's, Serao's prolific contributions to a considerable number of Italian newspapers and magazines (e.g. La Farfalla, Capitan Fracassa, Fanfulla della domenica, Il Giornale di Napoli, Cronaca Bizantina, Il Piccolo, La Gazzetta Letteraria Piemontese, and Roma Capitale) reveal her professional ambitions and her awareness of the rapidly growing press industry of the time. As she pointed out in an 1878 letter to her friend Gaetano Bonavenia, her determination to win a place in the burgeoning field of the press helped her surpass the limitations of her sex. ${ }^{1}$ More specifically, after co-founding the newspaper Il Corriere di Roma (1883-1886) with her husband Edoardo Scarfoglio and the daily Il Corriere del Mattino (1894) with Martino Cafiero, she became the editor of her own newspaper Il Giorno (1904-1927), which included contributions from some of the most prominent literary names of late nineteenth-century Italy (e.g. Gabriele D’Annunzio, Luigi Pirandello, Giovanni Pascoli, Anna Radius Zuccari, also known as Neera, Antonio Fogazzaro, and Giovanni Verga). In addition to her journalistic and editorial activities, Serao participated in the literary salons of Rome and Naples, which allowed her to extend her network of acquaintances and to engage in conversations about social issues and cultural events. As argued in one of her chronicles which appeared in the fortnightly periodical Cronaca Bizantina (Rome, 1881-1886), a competent salon hostess should have 'l'occhio acuto, la testa solida e la memoria forte: vede subito colei che entra, corre a salutarla, le fa la domanda opportuna' (Serao, 1883: 124). This description brought the Italian salonnière to the attention of a wider audience and offered a new reading experience to people who did not have access to the prestigious realm of the Roman salons.

The position of women in the cultural panorama of Italy offers a series of reflections on the years following the annexation of Rome in 1870 and the consolidation of the nation state. This period merits closer scrutiny because it offers an insight into the unprecedented expansion of the print industry and the rapid growth of the reading public. Social mobility, technological advances, the development of a national transport system, women's active participation in 
public and private debates as well as a wave of internal migration towards the new capital were some of the most important phenomena that contributed to the modernization and growth of the cultural production. Although a number of seminal studies on issues of femininity have already stressed women's central role in initiating and moderating private debates, these discussions almost always revolve around the literary salon of the Enlightenment and its gradual decline throughout the nineteenth century (Brambilla, 2013). In addition, approaches to Italian media history have pointed to the implications of women's participation in the press industry but focused on the symbiotic relationship between journalism and literature rather than the affinities between periodical editorship and salon participation (Schilardi, 1986). In seeking to explore Serao's mediation in the private as well as in the public sphere, this essay will examine the salon chronicles that she published in Angelo Sommaruga's Cronaca Bizantina. Salon descriptions which appeared in novels will also be discussed in order to nuance the similarities and differences between salon representations in fiction and in the press. Throughout the study, the following questions will be addressed: What aspects of modern life are highlighted in the chronicles and what meaning is projected upon them? How did the chronicles contribute to the understanding of Italian salon culture of the fin-de-siècle? Which image of modernity did Serao attempt to convey through her chronicles?

Critics have argued that the cultural modernization of Italy began soon after the political unification of the country (Hallamore Caesar, 2011: 14). In order to understand the processes of cultural production, it is pertinent to examine the role of the printed press in producing, reflecting and shaping culture. The case of Matilde Serao is particularly interesting because it offers a clear view of how private discussions were communicated to the public through the mediation of the salon chronicle. To study this connection, both salons and journals will be viewed as forums of culture, which enhanced literacy and strengthened collaborative efforts among men and women of letters. Some of the earliest and most compelling descriptions of Roman salons can be found in the permanent column entitled 'Salotti Romani', which appeared in the periodical Cronaca Bizantina in 1883. Preliminary considerations emphasize that although the Enlightenment literary salon developed historically from the aristocratic court, late nineteenth-century salons in Italy were distinctly populated by a growing bourgeoisie, which gathered regularly to discuss and make new acquaintances. Salon life as a meaningful social phenomenon was discussed in the pages of the Cronaca Bizantina in chronicles with the following titles: 'corrieri mondani', 'notte di buon gusto', and 'consigli per signorine'. Angelo Sommaruga, the editor of the periodical and a man of salons, outlined the aesthetic standpoint as well as the main objectives of his editorial endeavor: 'Aneliamo a creare un mondo nuovo da sostituire a quello che si sfascia [...] novi ordinamenti sociali, nuove istituzioni, nuove idee' (Sommaruga in Botonto, 1985: 198). As a permanent contributor to Sommaruga's periodical, Matilde Serao participated in the realization of this ambitious project and offered an acute analysis of modern urban life in the years following the Italian unification. She often signed her chronicles using the pseudonym L' Imbianchino and stressing the heterogeneous character of the salons that she attended in Rome. Each salon engaged in different causes and presented different social, artistic, and political features, which will be discussed in the present essay. Serao's attempt to interpret social reality and to study the salon as an inherent part of it was almost always accompanied by a tendency to contrast the 'old' world to the 'new' hence focusing on processes of modernization and social innovation. 
In her portrayal of Pasquale Mancini's salon in Rome, Serao underscored his position as Minister of Foreign Affairs and former editor of the Neapolitan periodical Le Ore Solitarie (1838-1842). The opening lines pay homage to his deceased spouse Laura Beatrice Oliva (18211869) who assisted him in establishing salons in Naples, Turin, Florence, Milan, and Paris during the turbulent years of his exile. Serao represented these salons as places in which ideas concerning the unification of Italy were openly exchanged and debated among members of the European political elite. In this regard, she argued that: 'Il ricevimento in casa sua è un brano di storia patria, è un frammento di letteratura poetica' (Serao, 1883: 120). This glorious past is contrasted to the post-unification period when Mancini's salon became a focal point for bohemian artists and gallant ambassadors. At this part of her chronicle, Serao introduced a shift in the perception of the literary salon from a place of political and intellectual fermentation to a hospitable and artistic manifestation, which promoted 'l'elemento lirico-musicalefilodrammatico-concertistico' (Serao, 1883: 121). This view is enhanced by Maria Luisa Berri and Elena Brambilla in the conference proceedings Salotti e ruolo femminile in Italia. In their analysis, they question the common normative stance, which sees salons mainly as places of socio-political dialogue. Instead, they argue that the cultural dynamics of the nineteenth-century salon stems from its ability to integrate artistic elements (e.g. music concerts, theatrical plays, lectures and readings) into its discourse (2004: 19). In the same vein, Serao portrays Mancini's salon as both a space for observation and knowledge and a forum which favors the literary and artistic production of modern Italy and is concerned with the preservation of its cultural heritage. The idea of cultural progress that Serao formulated in her chronicles aspired 'to reach a national audience that was perceived as physically and culturally distant and still fragmented' (Romani, 2013: 58). Given the transition from a fragmented state to a unified country, the salon could serve as a cultural reference that the two historical periods had in common. This reference would provide a sense of continuity between the past and the present thus reinforcing the idea of unity.

Serao's chronicle on Pasquale Mancini is evocative of what salons could offer to the modern urban landscape and to the social classes that had the opportunity to attend them: an access to concerts and theatrical performances, a possibility to meet with prominent literary and political figures from across Europe, and last but not least, a hope of aesthetic redemption and refinement. These observations stress the contemporaneity and immediacy of the salon experience and invite the readers of the chronicle to form their own views on a socio-cultural phenomenon that they experienced through and owing to the mediation of the press. In this regard, Gabriella Romani rightfully underscores that 'the topos of the salon acquired a symbolic value of escape into a world which people of the lower-middle classes could access only on the imaginative plane, as a fantastic projection of their desire of social mobility' (Romani, 2007: 243). Indeed, the readers of the chronicles were granted an imaginary access to the gallant world of the Roman salons. By addressing her readers directly, Serao brought them closer to the collective exchanges that took place in Mancini's house thus overlooking class or gender differences and rendering salon participation less exclusive. From this perspective, the chronicle served as a forum that allowed readers to form a micro community of virtual attendees who experienced salons in their own personal way.

Although subjectivity is a key element in perceiving the salon, the chronicle's potential to describe and interpret social behavior gives us a better idea of the journalist's objectives. In 
order to better understand these objectives, it would be helpful to look into Serao's analysis of the transnational literary networks that were formed in Mancini's salon. Among the attendees, Serao mentions the literary critic Camillo Boito (1836-1914) and the poet Andrea Maffei (17981885) but places a particular emphasis on lesser known female attendees such as Madame Lindstrand from Sweden, the Marquess del Mazo from Spain, and an opera singer Madame Adler from Germany. Although these names are now forgotten, they serve to highlight the cross-cultural character of Mancini's literary Fridays. Indeed, Serao stresses that 'il salotto Mancini è più, dirò così, europeo che diplomatico' (Serao, 1883: 121) a statement that has two main functions in the chronicle. First, it aims to pinpoint that the political character of the salon, which was significant during the pre-unification period (1815-1871), was to a certain extent overshadowed by its worldly character during the 1880 's. Second, it seeks to underscore that cosmopolitanism became one of the core values of modernity, which salon hostesses and attendees were eager to embrace. The term modernity is used in this essay as a framework for the analysis of Serao's salon chronicles and takes its cue from the work of Lino Rossi Estetica e metodo in which he argues that the idea of progress generates a fundamental hermeneutical need that is present in all modern societies (1990: 108). This observation leads to the conclusion that although the aesthetic dimension of Mancini's salon seems to cast a shadow over its political character, these two main aspects (the political and the aesthetic) continue to co-exist in Serao's chronicle because they satisfy the audience's need to understand and interpret social behavior. Hence, by bringing these two aspects of salon life to the attention of her readers, Serao urged them to view salon participation as a way of experiencing urban life through the prism of modernity.

The rapidly changing conditions of modern times posed several challenges to the social and aesthetic landscape of Rome. In an article that appeared in September 1883 in Corriere di Roma, Serao outlined a considerable increase in population and a subsequent need for an efficient plan of urban development. This was a subject of importance in salon conversations that Serao recorded for her audience: 'Due signori parlano di gran palazzi, di teatri, di quartieri nuovi da far sorgere per questa Roma nuova che cresce, che moltiplica, che ha bisogno di abitazioni commode, di edifici splendidi, di bellezza e di lusso' (Serao, Corriere di Roma, 1883: 148). This vision of Rome as an ancient city in urgent need of innovation was mediated in the press and allowed readers to observe its evolution and to form their own opinions on how to improve the quality of urban life. As a complement to this chronicle, Serao published an open letter on the $16^{\text {th }}$ of September 1883, criticizing the indifference of the political elites and addressing the residents of Rome: 'Ma la grande città è come percorsa da una vibrazione profonda, interiore: c'è qualche cosa che annunzia un palpito ancora, la risurrezione' (Serao, Corriere di Roma, 1883: 156). This view was enhanced once more in an article that appeared in the weekly magazine Fanfulla della domenica, where Serao expressed her stark convictions concerning the naturalness and inevitability of social and intellectual change:

Roma è stata, e sarà sempre la città della forza, della politica e degli affari [...] Uscite per un momento dai vostri sogni mistici e guardate l'immensa trasformazione che $\mathrm{i}$ milioni vanno inducendo nella forma e nello spirito di Roma. (Serao in Ghidetti, 1979: 20) 
This quotation lays bare that Rome, which only became the official capital of unified Italy in 1871, needed both to assume some of its traditional features and to evolve in new directions. Serao's imperative tone indicates the importance of collective participation in the process of modernizing 'the form and the spirit' of the newly established capital. It is noteworthy that in order to legitimize her argument, Serao used salon conversations as a proof of the centrality of the matter that she attempted to put forward to the audience. In other words, if a social issue was important enough to be discussed in the salons, then the press could contribute in taking the discussion further. In this regard, the emergence and consolidation of the salon chronicle seems to have served a triple purpose. First, it aimed to bring forward the chronicler's subjective impressions on the possible impact of the salons on public dialogue. Second, it sought to highlight the possibility of change and to implicate both the salon attendees and the reading audience in this process. Third, it offered general advice to the readers, especially to those of ascending bourgeois status, on how to participate in the public dialogue thus gaining an access to elite social circles. In light of these observations, the salon chronicle cannot be considered as a mere description of specific conversations among attendees. On the contrary, it is viewed as a means of social critique and a way to increase the participatory ethos of the readers ultimately giving rise to new conceptions of modern society.

In an attempt to describe a shift in the social function of the Roman salons, Serao published a lengthy chronicle on Francesca Gambacorta Magliani, a Sicilian Baroness who was married to the Minister of Finance, Agostino Magliani. Although her salon was originally represented as a space which favored the participation of women in the exchange of ideas, Serao condemned the paradoxical absence of political dialogue and noted that with the development of the print industry, salon life as a phenomenon of meaningful political import was coming to an end. As a renowned salonnière and a painter, Baroness Magliani was described as a promoter of young talents and a protector of the arts. The participants of her salon were invited to admire her private collections of paintings as well as to enjoy arias sung by Italian opera singers such as signore Matteini and Tiberini. Viewed from this perspective, the modern salon maintained its artistic significance and was still considered as one of the main venues for interaction and exchange. Although Serao praised this aspect of modern salon life, she continued her social critique by expressing her disillusionment over the indifference of female attendees with regard to the political and financial situation of post-unified Italy: 'Da tutto questo risulta una verità lampante: la politica è una fatalità, l'uomo politico è una necessità dolorosa' (Serao, 1883: 124). As this quotation suggests, political dialogue was a social necessity which the salon alone could no longer satisfy. The emergence and gradual proliferation of the press would thus complement the social function of the salon and encourage the circulation of ideas in society. As Ann Hallamore argues, the reach of print media in Italy was greater than the statistics on literacy and newspaper circulation suggest, even before the technological innovations of the early 1900's that gave rise to a sense of leggere per leggere (2011: 56). It is worth noting that the rise and consolidation of an empowered readership marked the end of the nineteenth century and legitimized the idea of reading for pleasure. Therefore, the public could interpret the reading of a salon chronicle as a pleasurable activity which offered an insight into the underexplored world of the salons. In this regard, Serao pointed out that the interrelation between salon life and modern journalism was crystallized in the salon chronicle, a genre that she proclaimed as the book to be done (Serao in Botonto, 1985: 297). 
Serao's ambivalent stance with regard to the participation of women in the political dialogue of their country merits further scrutiny. Although her general observations oppose women's active involvement in politics, her comments on the female attendees of Magliani's salon suggest a slightly different stance. More specifically, the disappointment that she expresses over the lack of women's critical thinking on the political landscape of modern Italy contradicts those parts of scholarship which qualify her views as conservative or anti-feminist. Such characterizations are problematic because they fail to take into consideration the impact of salon conversations on Serao's journalistic and editorial work. Intuition is yet another factor that plays a central role in her discourse about female participation in the public sphere. Serao affirms that women have a feeling for politics, which is presented as more valuable and useful to society than merely having political opinions: "In fatto di politica, le donne non hanno una opinione, hanno un sentimento" (Serao in Romani, 2013: 223). It is telling that Serao employs this argument in order to reinforce her views on the monarchy. Nevertheless, the impact of her discourse remains considerable given the ample dissemination of her articles and her assiduous participation in the Roman salons.

The focus of the chronicle on Magliani's salon then shifts from politics to the crosscultural exchanges between Italian and foreign attendees. In order to explore the intercultural communication encounters and the cosmopolitan spirit of this post-unification salon, Serao commented on the different nationalities of its main protagonists: the Roman Duchess of Gallese, the Italo-Egyptian Baroness Colucci, the Greek Princess Aristarki, the Austrian ambassador Ludolff, and finally the German Baroness of Arnim. The cosmopolitanism of Magliani's salon is connected to the need of the upper-classes to display at the international level the cultural significance of modern Italy and its legitimate place among other European nations. In this regard, Fulvio Cammarano underscores that the complicated process of legitimization involved a sense of openness towards other nations. ${ }^{2}$ This openness was expressed within the confines of urban salons either through an eagerness to explore foreign traditions and mores or through the will to translate and publish foreign literary works. Furthermore, the interactions among the salon participants underscore the transformative force of dialogue, which occupies a central role in Serao's chronicle. Magliani's salon is perceived not only as a space of artistic expression but it is also viewed as a collective experience, which allows individuals of different nationalities and cultural backgrounds to share their creative dispositions and aspirations. The cross-cultural nature of this encounter can lead to a better understanding of the ways in which foreign influences are integrated into the sphere of the salon and into society at large. In this regard, Banathy and Jenlink emphasize that the coming together of a community, no matter how diverse and heterogeneous, is the first step toward the integration of 'the foreign' and the creation of new cultural artifacts (Banathy and Jenlink, 2005: 3-5). Hence, the novelty that emerges from Magliani's salon is a sense of collaboration and cultural openness, which is mediated to the public through the chronicle. These two values are presented as quintessential within the context of modernity and offer a significant contribution to the public understanding of Italian salon culture.

Apart from highlighting the positive outcomes of salon sociability, Serao also drew her public's attention to the aspects of salon life that she considered problematic. Enrico Ghidetti briefly discusses her capacity to capture the conversational nature of the salon and to provide written proof of the activities that took place in the houses of the Roman upper class (Ghidetti, 
1979: 18-19). In his analysis of Serao's journalistic work, he seeks to elucidate the ways in which she understood and interpreted the functions of the salon chronicle as well as to explore the reasons why this new genre attracted the attention of a wide audience (Ghidetti, 1979: 20). As seen in the chronicles on both Mancini's and Magliani's salons, Serao praised the attendees' keen interest in the artistic landscape of their time but criticized female attendees for refusing to engage in political conversations. It is worth noting that although neither of these chronicles were written in the first person, Serao used a tone of irony to convey her disappointment regarding the predominance of aesthetics over reason. From this point of view, her chronicle functioned as a means for observation and social critique, which mediated effectively between the private and the public spheres. The following excerpt from Serao's correspondence with her Neapolitan friend Ulderico Mariani exemplifies this mediation and provides a critical view of women who participated in public conversations and private salons for the exclusive purpose of gaining or maintaining social visibility:

Queste donnine eleganti non sanno che io le conosco da cima a fondo, che le possiedo nella mia mente, che le metterò nelle mie opere, esse non hanno coscienza del mio valore della mia potenza. Mi trovano semplicemente charmante, io rido dentro di me. (Serao in Olivieri, 1990: 25)

As these observations suggest, Serao's integration in the salon circles of the capital was neither unhindered nor automatic. Although the salon of the late nineteenth century was no longer as politically oriented as it once was, it still functioned on the basis of exclusive membership and maintained its position as a symbol of past nobility. This lead Serao to view the salon chronicle as a space for analysis and interpretation. Part of this analysis suggests that the newspaper was more effective in producing and disseminating knowledge than the salon. Unlike the ritzy gatherings of the Roman bourgeoisie that allowed the circulation of news and ideas within the strict confines of privileged social classes, the periodical press offered an easier access to the cultural production of the time. In this respect, Wanda De Nunzio Schilardi, in her comprehensive study of Serao's journalism, emphasizes her affinity toward her female readers as opposed to her critical attitude toward some of the salon attendees (Schilardi, 1986: 73). This is confirmed by Serao's own argument according to which '1'unico milionario cui un giornalista debba chiedere l'appoggio è il pubblico' (Serao in Botonto, 1985: 82). This is telling of the appreciation that she showed to her audience and reflects a perspicacious assessment of the increasing power of the press. Another important factor that Silvia Franchini and Simonetta Soldani have brought to our attention is that processes of modernization in Italy were influenced by women's participation in the making of newspapers and journals: 'il binomio donne/giornalismo è come un segnale inequivocabile di ingresso nella contemporaneità e nella sfera del moderno' (Franchini and Soldani, 2002: 8-9). As this quotation suggests, women's journalistic writings gradually became an integral part of the Italian cultural panorama. This new reality influenced collective consciousness and forged new pathways towards a better understanding of women's place in the public sphere at the beginning of the twentieth century.

Despite the difficulties that Serao faced in accessing the elite spheres of the Roman salons and although she appeared to be more dedicated to her career as a journalist and an author than to her trajectory as a salonnière, she continued to publish salon chronicles for both personal 
and financial reasons (Gisolfi, 1960: 24). On the one hand, the interpretive function of these chronicles facilitated the public's global appreciation of salon culture. On the other hand, however, each chronicle fostered a deeper knowledge of the distinctive characteristics of each salon. An example that illustrates the co-existence of art and politics in modern salons can be found in Serao's chronicle on Francesco De Renzis and his wife Edith Sonnino, the Baroness di Montanaro. After a successful military career De Renzis established himself in Rome, where according to Serao, he became a regular contributor to the weekly magazine Fanfulla della domenica. It is not by coincidence that Serao's contribution to the same magazine as well as her active role in the journalistic circles of Rome offered her the opportunity to attend De Renzis' salon and to establish a friendship with the Baroness di Montanaro.

The intersection between salon life and journalism is made apparent in Serao's correspondence with her friend and renowned salon participant Giuseppe Primoli who also figured among the attendees of De Renzis' salon. In her letter, she evaluates this particular salon not as a mere social event but as an ideal place to converse, a 'luogo di conversazione' per excellence: 'il cui salotto fu per molti anni il più brillante di Roma, quello dove si passavano in rassegna tutte le manifestazioni dell'attività del pensiero d'Italia, dove si parlava egualmente di politica e d'arte' (Serao in Spaziani, 1962: 107). In contrast with the salons of Pasquale Mancini and the Baroness Magliani, which placed less emphasis on politics, Serao stressed that De Renzis' salon was more multifaceted and offered more opportunities to follow the political life of the capital. Along with his salon activities, she also praised the influential character of his contributions to the Fanfulla della domenica in an article that appeared in Corriere di Roma on the $16^{\text {th }}$ of September $1883 .^{3}$ This is telling of her triple role as journalist, editor, and salon participant as well as of her capacity to promote the work of people who already formed part of her network of acquaintances. This network was further expanded through her participation in the renowned salon of the Roman daily newspaper Capitan Fracassa, which was edited by Gennaro Minervini.

Although Serao wrote assiduously on salons that she attended in the houses of the Roman upper class, the editorial offices of the leading contemporary literary magazines (mainly Cronaca Bizantina and Capitan Fracassa) functioned as salons in their own right and soon became focal points for Italian and foreign intellectuals. These salons helped shape the new cultural climate of Rome, which came to be known as a 'capitale bizantina' implying an air of sumptuousness and decadence. The vitality of the periodical press in shaping this particular image of the capital is conspicuous in D'Annunzio's articles for the Fracassa. This is where he highlighted Rome's privileged position as the main locus where the cultural and social elites converged and where a new identity for modern Italy was being forged (Pieri, 2007: 59). Serao began her long-lasting collaboration with D'Annunzio as well as with Giuseppe Carducci in 1882 when she joined the editorial team of the Fracassa. Before long, she started to attend the literary gatherings that were held in the editorial office of the newspaper. Luigi Lodi, another one of her colleagues, recollects that she was not a mere contributor but a 'redattrice fissa e ordinaria' whose successful mediation between the periodical press and the literary salons aroused mixed feelings of admiration and envy:

Nel salotto del giornale [Fracassa] che pareva riservato a personaggi illustri, quella giovane donna ancora pressoché ignota acquistò presto invidiabili considerazioni, che 
si diffusero sollecitamente intorno a lei. E allora, anche i salotti le si aprirono: fu invitata ed accolta con evidente deferenza. (Lodi in Gisolfi, 1960: 25-26)

The wide acceptance of Serao's work and personality counterbalanced the criticism that she received for being a journalist from Naples who nourished Roman ambitions. Her uninhibited attitude and realistic descriptions as well as a sense of rumorosa discorsività seem to have been the most outstanding characteristics of her salon chronicles, which earned her a number of admirers as well as a number of enemies. When asked to comment on the position of the chronicler, she argued that too many personal statements and an excessively elaborate style were likely to give a false impression on the salon life of the capital. Her idea of a good chronicler was an extroverted person who could move freely in and out the salon circles in order to talk to everyone, go anywhere, see everything and then 'render' all this to the public, in a simple way without hymns and exaltations (Serao in Botonto, 1985: 297). This approach leads us to the conclusion that Serao incorporated the salon into her journalistic writings without making it seem more attractive than it was in reality. This is also obvious from a chronicle that she wrote on the social milieu that gravitated around the salon of the Fracassa. Although Serao acknowledged the prestige of this particular salon, she did not introduce it to her readers as an apt example of modern sociability and conviviality. Instead, she argued that its participant's objective to influence public discourse was in fact sabotaged by their perception of modernity. According to this approach, the salon of the Fracassa underwent an uncontrollable expansion, which Serao viewed as an inherent characteristic of the modern movement. With the increasing dissemination of the press and the emergence of new technologies, all other aspects of modern life were constrained to keep up with an unprecedented pace of development. As a consequence, Serao stressed that the salon of the Fracassa lost its exclusive character and became the victim of a persistent demand for expansion:

Il salotto del Capitan Fracassa, che ha già una storia e una leggenda, subisce esso pure l'incubo di quest'allargamento, che si direbbe la caratteristica del movimento moderno, il quale allarga tutto: il suffragio, le vie, le idee, i ventagli, gli ombrelli, il formato dei giornali (Serao in Ghidetti, 1979: 127).

A conclusion that emerges from this quotation is that the Capitan Fracassa was a project which had its roots in the modern era. Either in the form of a newspaper or in the form of a salon, this project set out to meet the challenges of a new period and in doing so it needed to adhere to the ideas and the concepts that were forged within the specific context of its time. Hence, Serao links the expansion of human activities to the nascent modern movement and attributes a negative meaning to the concept of the 'expansion' arguing that objects (e.g. umbrellas) as well as ideas (e.g. suffrage) were inevitably subjected to it. This rather bleak view of modernity that she forged in her writings is counterbalanced by a faint hope of aesthetic redemption and progress. It is characteristic that as she proceeds in her analysis of Fracassa's salon, she does not make any counter-proposition to stop the expansion from taking place. It is evident, from her standpoint, that despite its shortcomings this new tendency could also lead to positive outcomes. Such an outcome was the expansion of literacy, which was largely attributed to the public's increased accessibility to written texts. By taking into consideration both aspects 
of this chronicle, it is possible to understand Serao's skepticism as a productive attitude, which questions the aesthetic and intellectual challenges of the fin-de-siècle period. A skeptical attitude towards the functions and role of the intellectual circles is also conspicuous in the descriptions of salon life that we encounter in Serao's novels.

In the novel Cuore infermo, which was originally published in 1881, Serao juxtaposes two female characters who embody different attributes. On the one hand, Beatrice appears as the archetypal virtuous heroine whose righteousness and passivity make her inaccessible to her husband Marcello Sangiorgio. Lalla, on the other hand, is endowed with the attributes of the passionate woman (femme fatale) who pursues a love affair with Marcello. The two women meet each other at a friend's salon in Naples, where Lalla expresses a keen interest in her lover's wife "turning her head to her, as if she wanted to talk to her" and confessing to a would-be suitor that she "even loves the Duchess Sangiorgio" (Serao, reprint 1988: 174). "You love too much, Countess", is his observation to which she responds: "It is my defect. Ask Marcello about it" (Serao, reprint 1988: 176). This passage shows that the salon was often the setting where passions took place. The intimate tone with which Serao narrates the story of Beatrice and Lalla draws the attention of the readers to the intimate aspect of salon life. By examining the emotions of the attendees, Serao not only stresses the different personalities of women who frequented the salons, the virtuous woman and the femme fatale, but she also makes an implicit comment about the frivolity of the worldly circles of her time.

In a similar vein, Luigi Pirandello's novel Suo marito (1911) explores the adventures of Attilio Raceni who is a frequent salon attendee and an editor of a magazine for women, which he qualifies as 'femminile' rather than 'feminista'. Part of the intrigue takes place in the salon of his friend Dora Barmis, an ambitious woman who tries to make her way into the intellectual circles of her time by establishing frivolous relationships with the attendees of her salon. The social milieu that she frequents is described as superficial and nonchalant, a critique of salon life that Pirandello put forward in order to attack the idleness of the intelligentsia. It is therefore possible to trace a similar attitude both in Serao's and Pirandello's novels. Their critical stance towards the people who were expected to influence the socio-political landscape of modern Italy aimed to raise awareness on the role of the intellectuals in society. This stance would also help the readers form their own views on the utility of salon circles. Although the salon descriptions that can be found in novels differ in style and tone from those that appeared in the press, they both served as departure points for reflection and observation. Descriptions in novels are more personalized and reveal the intimate intricacies of salon life whereas salon chronicles maintain a more neutral tone and examine the salon as a socio-political and an aesthetic phenomenon. In both of these cases, however, the common goal was to initiate a thought process on aspects of modern life in post-Unification Italy.

To conclude, the salon descriptions examined in this essay combine three features: the chronicler-narrator, the socio-political landscape of Rome, and the specific conditions that prevailed in each salon. These features help us rethink the fin-de-siècle salon through the prism of the periodical press, which offered different views on salon culture and played a decisive role in enhancing its dissemination to a wider audience. Two main approaches emerge from Serao's chronicles. The first one explains the salon as a social phenomenon that gave way to reflections on the growing demand for human progress, the withering away of politics, the advantages and drawbacks of the 'civilizing' mission of modernity, and the growing importance 
of art as a means of personal expression. These interrogations are present in Serao's chronicles and encourage the readers to take an interest in private conversations and debates thus forming an imagined community of salon goers. The second approach to the Roman salons of the late nineteenth century is more critical. Serao uses the salon chronicle not as a mere representation of a collective experience but as an instrument of social critique which targets the exclusive character of the salons and the indifference of the participants. Hence, her double role as chronicler and salon attendee allows her mediation between private conversations and public discourse and legitimizes her position as arbiter of social values.

Whilst emphasizing the novelty of the periodical Cronaca Bizantina in addressing the need for cultural and aesthetic renewal, Angelo Sommaruga gave up its editorship in 1885 when D'Annunzio took over the publication of the new series entitled Nuova Bizantina. This series drew attention to the emergence of a new aestheticism inspired by the English Pre-Raphaelite movement. After the publication of a few issues, however, the series ceased to appear in 1886 . Similarly, the publication of the Capitan Fracassa was suspended in 1890, when it stopped functioning as a literary salon and a major point of reference for the artistic and intellectual circles of the city. Nevertheless, Serao's contribution to the understanding of salon life was already conspicuous in her chronicles. By the end of her Roman period, which lasted from 1882 to 1886 , the dissemination of her work was facilitated with the rapid expansion of the print industry and through the connections that she established with other journalists, writers, and salon participants. During that period she questioned the social functions of the literary salon and developed her critique of contemporary society thus inviting her readers to reflect on the challenges of the modern period. After obtaining a rich journalistic experience in Rome, she returned to Naples, where she began editing the weekly magazine La Settimana (1902-1904) and the daily newspaper Il Giorno (1904-1927). This is where she would continue her observation of society while ironically juxtaposing the ascension of the nuova borghesia to the notorious ventre di Napoli.

\section{Notes}

${ }^{1}$. In this regard, see Matilde Serao in Laura A. Salsini. Gendered Genres: Female Experiences and Narrative Patterns in the Works of Matilde Serao. London: Associated University Press, 1999, p.19: "I am writing everywhere and about everything, with a singular audacity, I am winning my place by dint of pushing and shoving, with the absolute burning desire to get there without anyone helping me, or hardly anyone. But you know that I don't listen to the weaknesses of my sex and I keep going as if I were a young man”.

2. Fulvio Cammarano, 'Les elites políticas y la construcción del estado liberal en Italia (18611901)' in Renato Camurri and Rafael Zurita (eds.) Las elites en Italia y en España (1850-1922). Valencia: Universitat de València, 2008, p.43: “A diferencia de lo sucedido en otras realidades europeas, la construcción de la 'nación', realizada sobre la base de un complejo mosaico de sistemas políticos y estadios de desarrollo social, planteo a las clases dirigentes liberales italianas un difícil problema de legitimación”. 
3. Matilde Serao, 'Lettera senza indirizzo', Corriere di Roma, 16 settembre 1883.

\section{References}

Banathy B and Jenlink P (2005) Dialogue as a Means of Collective Communication. New York: Kluwer Academic/Plenum Publishers.

Berri M and Brambilla E eds. (2004) Salotti e ruolo femminile in Italia: tra fine Settecento e primo Novecento. Venice: Marsilio.

Botonto T (1985) Matilde Serao Giornalista. L'Albero, Edizioni Milella, n.73-74, pp.297-299.

Brambilla E (2013) Sociabilità e relazioni femminili nell'Europa moderna. Milan: Franco Angeli.

Camurri R and Zurita R eds. (2008) Las elites en Italia y en España (1850-1922). Valencia: Universitat de València.

Franchini S and Soldani S (2002) Donne e giornalismo. Percorsi e presenze di una storia di genere. Milano: Franco Angeli.

Ghidetti E (1979) Roma Bizantina. Milan: Longanesi.

Gisolfi A (1960) Matilde Serao's Conquest of Rome (1882-1886). Italica, March, Vol. 37, No. 1, pp. 22-43.

Hallamore Caesar A, Romani G and Jennifer B (2011) Printed Media in Fin-de-siècle Italy: Publishers, Writers, and Readers. London: Modern Humanities Research Association.

Mitchell K (2008) La Marchesa Colombi, Neera, Matilde Serao: Forging a Female Solidarity in Late Nineteenth-Century Journals for Women. Italian Studies, Vol. 63, No.1, pp. 63-84.

Olivieri M (1990) Tra libertà e solitudine. Saggi su letteratura e giornalismo femminile. Rome: Edizioni dell'Ateneo.

Palazzolo, M (1985) I salotti di cultura nell'Italia dell'Ottocento. Scene e modelli. Milan: Franco Angeli.

Pieri G (2007) The Influence of Pre-Raphaelitism on Fin de Siècle Italy: Art, Beauty, and Culture. London: Maney Publishing.

Pirandello L (1911) Suo marito. Florence: Quattrini. 
Romani G (2007) A Room with a View: Interpreting the Ottocento through the Literary Salon. Italica, Vol. 84, No. 2/3, pp. 233-246.

Romani G (2013) Postal Culture: Writing and Reading Letters in Post-Unification Italy. Toronto: University of Toronto Press.

Rossi L (1990) Estetica e metodo: la scuola di Bologna. Bologna: Nuova Alfa.

Salsini L (1999) Gendered Genres: Female Experiences and Narrative Patterns in the Works of Matilde Serao. London: Associated University Press.

Schilardi W (1986) Matilde Serao giornalista. Lecce: Editore Milella.

Serao M (1881) Cuore infermo. Reprint 1988, Rome: Lucarini.

Serao M (1883) 'Casa Mancini’, Cronaca Bizantina, 1st March.

Serao M (1883) 'Casa Magliani’, Cronaca Bizantina, 16th March.

Serao M (1883) Corriere di Roma, 1st September. 